Bangladesh J. Bot. 49(4): 989-996, 2020 (December)

\title{
NATURAL REGENERATION POTENTIAL OF MADHUPUR NATIONAL PARK, BANGLADESH
}

\author{
Md Rayhanur Rahman, MK Hossain*, Md Akhter Hossain and \\ Mohammad Emran Hasan ${ }^{1}$ \\ Institute of Forestry and Environmental Sciences, University of Chittagong, \\ Chittagong-4331, Bangladesh
}

Keywords: Natural regeneration, Tree diversity, Value index, Anthropogenic disturbances

\begin{abstract}
Natural regeneration is an essential tool to evaluate the overall health of a forest ecosystem. Natural regeneration of the tree species in Madhupur National Park showed 47 regenerating tree species among which Shorea robusta has maximum density (18,046 seedlings per ha) followed by Aporosa sp., whereas minimum density (19 seedling per ha) was recorded for Cassia nodosa, Litsea glutinosa, Grewia asiatica and Syzygium cumini, respectively. Relative density, relative frequency and relative abundance were estimated to assess the Importance Value Index (IVI) of the seedlings of different tree species. IVI of S. robusta was highest (66.25 out of 300) followed by Mallotus philippensis (27.33). G. asiatica, Derris robusta, and $L$. glutinosa showed the lowest IVI (0.93) among the regenerating tree species. Distribution of seedlings into different height classes showed that maximum number (31.4\%) of seedlings in the height range of $50-<100$ $\mathrm{cm}$. Among the recorded seedlings, Protium serratum showed maximum (11\%) recruitment success. Alien invasive species, pineapple and banana based participatory agroforestry, frequent occurrence of fire, extensive collection of fuelwood and litter are the potential threats to the natural regeneration of Madhupur National Park.
\end{abstract}

\section{Introduction}

Natural regeneration is a natural biological process of forest resources reproduction in forest ecosystem. It caused the assessment of regeneration to be an authentic tool to know the overall condition of forest (Wang et al. 2008, Rahman et al. 2019). Through the natural regeneration process tree dominant plant communities developed and evolved, which has far reaching impact on the structure of forest (Han and Wang 2002). Moreover, regeneration is essential for conservation and maintenance of floral diversity in natural forests (Hossain et al. 2004, Rahman et al. 2011). Plants maintain and expand their populations in time and space through the regeneration process. This complex ecosystem process involves asexual and sexual reproduction, dispersal of seed and establishment seedlings in relation to environmental factors (Barnes et al. 1998). However, the pattern of population structure of woody plants can show the regeneration profile, which is used to determine their regeneration status (Taketay 1996).

Madhupur National Park (MNP), the oldest protected area (PA) comprises a significant part of tropical moist deciduous forest in the central region of Bangladesh. The forest patches of this PA are being encroached and degraded day by day mainly due to anthropogenic disturbances (Rahman et al. 2017). Prain (1903) emphasized the exploration of the Madhupur forests which occupies the major Sal forests of the country. Some studies were conducted in MNP or associated Sal forest to explore the flora with particular importance to tree flora i.e. Sattar (1977), Alam (1995), Harun-Or-Rashid and Mia (2001) and Malaker et al. (2010). But, no reports are available on the restoration potentials through natural regeneration. It is important to know the natural

*Author for correspondence: <mkhossain2009@gmail.com>. ${ }^{1}$ Former Geospatial Analyst, International Union of Conservation of Nature, Bangladesh. 
regeneration and recruitment of the regenerated seedlings along with their diversity and composition for undertaking and prioritizing management prescriptions. In this circumstance, the study was undertaken to explore the status of natural regeneration of MNP and compare the restoration potentials of this PA with other similar forests. Outcomes of the study is expected to be helpful to relevant policy makers and forest managers to decide and undertake species specific conservation measures for the seedlings of threatened or rare plants of this park.

\section{Materials and Methods}

Madhupur National Park located at 125 kilometers north of Dhaka covering the land area between $24^{0} 30^{\prime}$ to $24^{\circ} 50^{\prime} \mathrm{N}$ latitude and $90^{\circ} 00^{\prime}$ to $90^{\circ} 10^{\prime} \mathrm{E}$ longitude is situated on the western side of Tangail-Mymensingh main road (Rahman et al. 2017). Administration of the park is under the jurisdiction of Tangail Forest Division (Begum 2011). The park consists of an area of 8,436 ha (20,845.81 acre) of which 8,195.8 ha are under Madhupur Upazila of Tangail district and 240.2 ha are in Muktagacha Upazila of Mymensingh district. The Madhupur Garh forms a slightly elevated tract with maximum height of about $18-20 \mathrm{~m}(60-85$ feet) from the mean sea level. The soil of Madhupur Sal forest is mixed with yellowish red sandy clay. The soil is compact and hard when dries but melts with the rainfall and becomes soft and tenacious (Mondol 2013).

The field survey was conducted in 4 forest beats of Madhupur National Park. To assess the regeneration status the field work was done through quadrat survey method from January, 2015 to June, 2016. Sample plot survey was fixed to $3 \mathrm{~m} \times 3 \mathrm{~m}$ with the help of species area curve. A total of 58 sample plots were taken from all the four beats, e.g. Sadar beat, Lahoria and Gasabari beats of MNP Sadar range and Sadar beat of Dokhola range randomly. Position of each sample plot was recorded by a Ground Positioning System (GPS) device for future monitoring studies. Forest type and disturbance that affect the regeneration of the tree species were recorded for each sample plot. The seedlings were identified and counted by species as well as their heights were measured.

The recorded seedlings were identified in the field by their local or scientific names to the extent possible. Plant samples from the unknown seedlings were collected to prepare herbarium specimen. Taxonomists from the Department of Botany, University of Chittagong and the Bangladesh Forest Research Institute (BFRI) helped in identifying the unknown species.

The data were analyzed for assessing the regeneration composition, relative density (RD), relative frequency (RF), relative abundance (RA) and importance value index (IVI) for each species following Misra (1968), Dallmeier et al. (1992) and Shukla and Chandel (2000).

\section{Results and Discussion}

The native tree species were regenerating naturally through seeds, coppice and root suckers. The study revealed that 47 tree species belonging to 24 families and 42 genera were regenerating naturally. Physical observation indicated that most of the regeneration occurred from seed where a few were found to grow from coppices. However, the regeneration species composition is less than that of Dudhpukuria-Dhopachari Wildlife Sanctuary (120 species), Chunati Wildlife Sanctuary (105 species), Khadimnagor National Park and Tilagor Eco-Park of 55 species (Rahman et al. 2011, Hossain et al. 2013a, Hossain and Hossain 2014). But, the number of regenerating tree species is higher than that of Tankawati Natural Forest of Chittagong South Forest Division (29 tree species) (Motaleb and Hossain 2011) and Durgapur hill forest of Netrokona (27 tree species) (Rahman et al. 2019a). In addition, Deb et al. (2015) recorded the total regenerated understory species was 61 belonging to 27 families but it is not easy to compare with their findings because they have considered not only seedlings but also saplings. Disturbance in natural forests can change habitat suitability of plant species (Wilcox et al. 2006) which affects plant species 
Table 1. Regenerating tree species with seedling density, frequency, abundance and importance value index (IVI) in Madhupur National Park

\begin{tabular}{|c|c|c|c|c|c|c|c|}
\hline No. & $\begin{array}{l}\text { Scientific } \\
\text { name }\end{array}$ & $\begin{array}{l}\text { Local } \\
\text { name }\end{array}$ & $\begin{array}{l}\text { Seedlings/ } \\
\text { ha }\end{array}$ & $\begin{array}{l}\mathrm{RD} \\
(\%)\end{array}$ & $\begin{array}{l}\text { RF } \\
(\%)\end{array}$ & $\begin{array}{l}\text { RA } \\
(\%)\end{array}$ & IVI \\
\hline 1 & Albizia procera & SadaKoroi & 77 & 0.18 & 0.47 & 1.31 & 1.95 \\
\hline 2 & Antidesma ghaesembilla & Chokoi & 498 & 1.17 & 3.03 & 1.31 & 5.51 \\
\hline 3 & Aporosa sp. & Aporosa & 3142 & 7.35 & 6.76 & 3.70 & 17.82 \\
\hline 4 & Artocarpus lacucha & Borta & 38 & 0.09 & 0.47 & 0.65 & 1.21 \\
\hline 5 & Bauhinia malabarica & Choka kola & 96 & 0.22 & 0.47 & 1.64 & 2.33 \\
\hline 6 & Bridelia tomentosa & Sitki & 2165 & 5.07 & 6.29 & 2.74 & 14.10 \\
\hline 7 & Careya arborea & Gadila & 517 & 1.21 & 1.86 & 2.21 & 5.28 \\
\hline 8 & Cassia fistula & Sonalu & 153 & 0.36 & 1.40 & 0.87 & 2.63 \\
\hline 9 & C. nodosa & Bon-Sonalu & 19 & 0.04 & 0.23 & 0.65 & 0.93 \\
\hline 10 & Cleistocalyx nervosum & Ludijam & 153 & 0.36 & 0.47 & 2.62 & 3.44 \\
\hline 11 & Cordia dichotoma & Bohal & 38 & 0.09 & 0.23 & 1.31 & 1.63 \\
\hline 12 & Cryptocarya amygdalina & Ojha & 1303 & 3.05 & 4.66 & 2.23 & 9.94 \\
\hline 13 & Derris robusta & Katenga & 96 & 0.22 & 0.70 & 1.96 & 2.88 \\
\hline 14 & Dillenia pentagyna & Ajuli & 153 & 0.36 & 1.17 & 1.05 & 2.57 \\
\hline 15 & Ficus hispida & Dumor & 77 & 0.18 & 0.47 & 1.31 & 1.95 \\
\hline 16 & Garuga pinnata & SadaJiga & 268 & 0.63 & 1.63 & 1.31 & 3.57 \\
\hline 17 & Glochidion multiloculare & Chokoi & 268 & 0.63 & 0.23 & 9.16 & 10.02 \\
\hline 18 & Grewia asiatica & Kapaia & 19 & 0.04 & 0.23 & 0.65 & 0.93 \\
\hline 19 & G. nervosa & Datoi & 1571 & 3.68 & 4.43 & 2.83 & 10.93 \\
\hline 20 & G. serrulata & Kholladamor & 364 & 0.85 & 1.63 & 1.78 & 4.26 \\
\hline 21 & Haldina cordifolia & Haldu & 153 & 0.36 & 0.47 & 2.62 & 3.44 \\
\hline 22 & Hymenodictyon orixensis & Bhutum & 249 & 0.58 & 1.86 & 1.06 & 3.51 \\
\hline 23 & Lagerstroemia parviflora & Sidha & 96 & 0.22 & 0.70 & 1.09 & 2.01 \\
\hline 24 & L. speciosa & Jarul & 153 & 0.35 & 0.93 & 2.18 & 3.47 \\
\hline 25 & Lannea coromandelica & Jiga & 211 & 0.49 & 1.17 & 1.44 & 3.10 \\
\hline 26 & Litsea glutinosa & Menda & 19 & 0.04 & 0.23 & 0.65 & 0.93 \\
\hline 27 & Mallotus philippensis & Sinduri & 3084 & 7.22 & 5.59 & 4.39 & 27.33 \\
\hline 28 & Miliusa velutina & Gandhi gajari & 364 & 0.85 & 2.80 & 1.04 & 4.69 \\
\hline 29 & Mitragyna parvifolia & Futikadam & 115 & 0.27 & 0.47 & 1.96 & 2.70 \\
\hline 30 & Oroxylum indicum & Thona & 939 & 2.20 & 5.13 & 1.46 & 8.78 \\
\hline 31 & Phyllanthus emblica & Amloki & 153 & 0.36 & 1.17 & 1.05 & 2.57 \\
\hline 32 & Protium serratum & Neur & 307 & 0.72 & 1.86 & 1.31 & 3.89 \\
\hline 33 & Schleichera oleosa & Kusum & 402 & 0.94 & 1.86 & 1.72 & 4.52 \\
\hline 34 & Semecarpus anacardium & Bheula & 192 & 0.45 & 1.40 & 1.09 & 2.94 \\
\hline 35 & Shorea robusta & Sal & 18046 & 42.24 & 12.59 & 11.42 & 66.25 \\
\hline 36 & Spondius pinnata & Amla & 96 & 0.22 & 1.17 & 0.65 & 2.04 \\
\hline 37 & Sterculia villosa & Udal & 172 & 0.40 & 1.17 & 1.18 & 2.75 \\
\hline 38 & Streblus asper & Sheora & 1284 & 3.00 & 3.73 & 2.74 & 9.48 \\
\hline 39 & Suregada multiflora & Suregada & 153 & 0.36 & 0.47 & 2.62 & 3.44 \\
\hline 40 & Syzygium cumini & Kalojam & 19 & 0.04 & 0.23 & 0.65 & 0.93 \\
\hline 41 & S. fruticosum & Putijam & 210 & 0.49 & 1.63 & 1.96 & 4.09 \\
\hline 42 & Tamilnadia uliginosa & Pirilagota & 594 & 1.39 & 2.09 & 3.10 & 6.59 \\
\hline 43 & Terminalia bellirica & Bohera & 2490 & 5.83 & 4.66 & 4.25 & 14.75 \\
\hline 44 & Vitex glabrata & Baskura & 77 & 0.18 & 0.70 & 0.87 & 1.75 \\
\hline 45 & Wrightia arborea & Dudhkuruch & 421 & 0.99 & 2.80 & 1.20 & 4.98 \\
\hline 46 & Zanthoxylum rhetsa & Bajna & 172 & 0.40 & 2.10 & 0.65 & 3.16 \\
\hline 47 & Ziziphus rugosa & Anaigota & 96 & 0.22 & 0.93 & 0.82 & 1.97 \\
\hline Total & & & 41,282 & 100 & 100 & 100 & 300 \\
\hline
\end{tabular}


composition and ecosystem functions (Berhane et al. 2013). Human-induced disturbances and influences, such as logging, browsing and grazing can significantly modify species diversity and composition. As intensity and frequency of disturbance increases, the availability and abundance of many species could decline with increased risk of local extinction. More abundant and generalized species are less vulnerable to disturbance than rare and specialized species. Disturbance can also change the gap sizes in forest and alter species composition by encouraging pioneer plant species. Madhupur National Park is tremendously disturbed by the local people, but existing control measures are very inadequate to address the issues. As per the findings of the study, the number of species showed the suitability of the forest for regrowth if kept undisturbed.

Among the regenerating tree species, S. robusta (18,046 seedlings and saplings per ha) showed highest density followed by Aporosa spp. (3142 seedlings and saplings per ha), $M$. philippensis (3084 seedling per ha), and T. bellirica (2490 seedling per ha). Besides, minimum seedling density (19 seedling per ha) was recorded for C. nodosa, L. glutinosa, G. asiatica and S. cumini, respectively. The maximum relative density $(42.24 \%)$ was recorded for $S$. robusta followed by Aporosa sp. (7.35\%), M. philippensis (7.22\%), T. bellirica (5.83\%), whereas maximum relative frequency (12.59\%) was recorded for S. robusta followed by Aporosa sp. $(6.76 \%)$, B. tomentosa $(6.29 \%)$, M. philippensis $(5.59 \%)$. Highest relative abundance $(11.42 \%)$ was recorded for $S$. robusta followed by G. multiloculare (9.16\%), M. philippensis (4.39\%), and T. bellirica (4.25\%). However, those results are comparable with the findings of Nur et al. (2016) where they found Bursera serrata, Toona ciliata, Stereospermum chelonoides, Ficus hispida, Macaranga denticulata, Callicarpa macrophylla, and Syzygium fruticosum were dominating (higher numbers of seedlings/ha) among the regenerated tree species at Shitalpur Forest Beat of Chittagong North Forest Division. The IVI values indicating overall dominance of a species in the study area (Das et al. 2018) where the maximum IVI value was for S. robusta (66.25 out of 300) followed by M. philippensis (27.33), Aporosa sp. (17.82), T. bellirica (14.75), G. nervosa, B. tomentosa (14.10). On the contrast, G. asiatica, D. robusta, L. glutinosa showed the lowest regeneration IVI (0.93) of the regenerating tree species. However, Chowdhury et al. (2018) studied regeneration diversity of Rampahar Natural Forest Reserve in Rangamati South Forest Division, where they recorded the IVI values of regenerating tree species was highest in P. serratum (50.09) followed by B. ceiba (39.37).

There is lack of published information about the phytosociological attributes of regenerating tree species for similar forests (i.e. deciduous or Sal forest). When compared with the mixed evergreen tropical forests of nearby areas, it was found that Dipterocarpus turbinatus (IVI 25.94) is the most frequent regenerating tree species in Dudhpukuria-Dhopachari Wildlife Sanctuary followed by Aporosa wallichii (12.36) (Hossain et al. 2013a). Rahman et al. 2019 reported Lepisanthes rubiginosa (IVI 27.59) as the most dominant regenerating tree species in Hazarikhil Wildlife Sanctuary which was followed by Ficus hispida (IVI 21.18). Moreover, Kamruzzaman et al. (2018) showed Suregada multiflora (IVI 21.36) as the profusely regenerating tree species followed by Brownlowia elata (IVI 18.73) and Protium serratum (IVI 17.69) in a community forest of Bandarban named Babu Para Village Common Forest. The cited literatures indicated that though the forests are of different in nature than the studied Sal forest but there are some species having common in both forest types possessing good regeneration potential.

The percentage distribution of all the recorded seedlings of all species is shown in six height (cm) classes, e.g. 0 - $<50 \mathrm{~cm}, 50-<100 \mathrm{~cm}, 100-<150 \mathrm{~cm}, 150-<200 \mathrm{~cm}, 200-<250 \mathrm{~cm}, 250-$ $<300 \mathrm{~cm}$. It was found that maximum (31.4\%) seedlings were within a height range of $50-<100$ $\mathrm{cm}$, whereas, only $0.7 \%$ saplings were found in $(250-<300) \mathrm{cm}$ height range (Fig. 1). However, present findings are almost similar to the findings reported by Misbahuzzaman and Alam (2006) who reported highest seedlings in height class $1-<2 \mathrm{~m}$ from natural forest of Sitakunda, 
Chittagong. Disturbances were noticed to the regenerating trees in the early stages of the regeneration process. The main disturbances are environmental stress, e.g. exposure to open sun light, moisture deficient and/or anthropogenic factors, e.g. grazing, firewood collection or intentional fire in dry seasons. On the other hand, collection of sapling and pole by local people for fencing resulted in reduced percentage in the higher height classes.

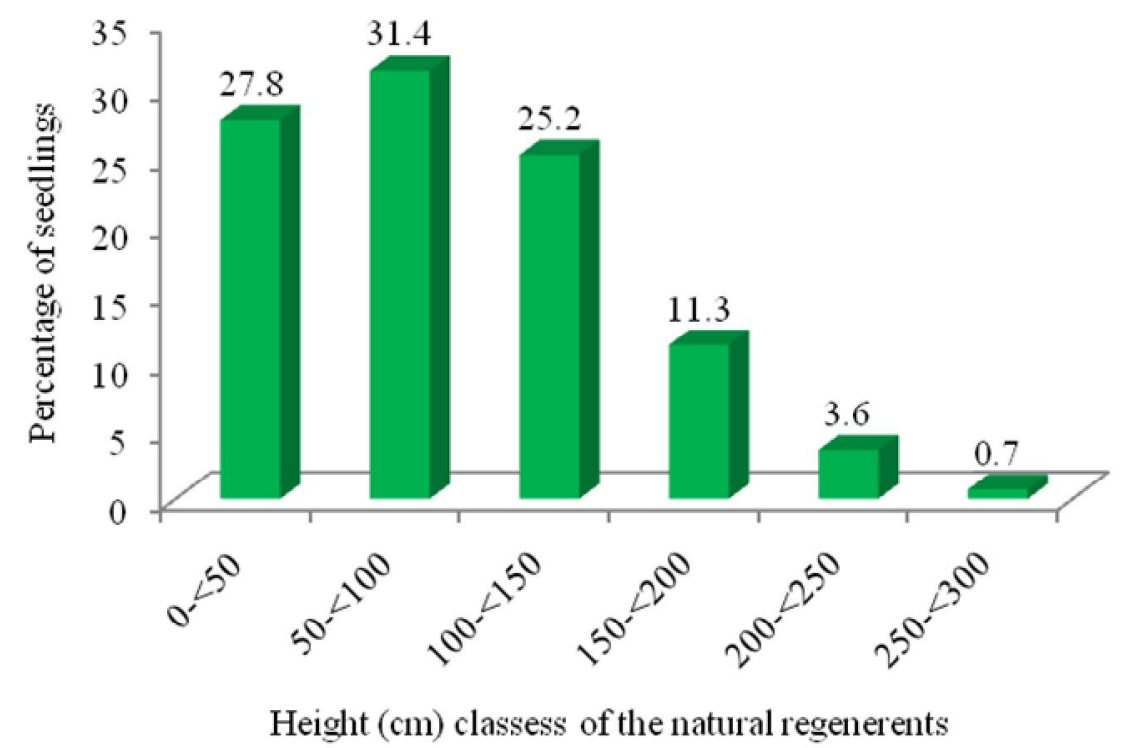

Fig. 1. Percentage distribution of the seedlings into different height $(\mathrm{cm})$ classes.

A comparison among the number of seedlings of five dominating tree species with their corresponding tree stems per hectare shows that P. serratum has maximum $(11 \%)$ seedling recruitment percentage followed by S. robusta (6\%), M. phillippensis (2\%) and G. nervosa (2\%) (Table 2). Though seedling density of $S$. robusta is maximum but its recruitment percentage is lower than $P$. serratum. It might be due to collection of young poles for fence post or other purposes by the local people. However, Hossain and Hossain (2014) reported that in Chunati Wildlife Sanctuary the dominant natural tree species was Dipterocarpus alatus which showed maximum (11\%) seedling recruitment percentage followed by Lithocarpus polystachya $(5 \%)$ and Syzygium fruticosum (5\%).

The research explored the natural regeneration composition of tree species, phytosociological attributes of the regenerating species, height class distribution and recruitment status of the seedlings in Madhupur National Park. MNP being a major representative of the Sal forest of Bangladesh indicated a good number of naturally regenerating species (47 species) where $S$. robusta is the most dominant one followed by M. philippensis. The study also indicated that recruitment percentage of $P$. serratum is maximum followed by $S$. robusta and M. philippensis. The frequent fire and indiscriminate cutting of the $S$. robusta pole may cause comparatively lower percentage of recruitment. Presence of 47 regenerating tree species exhibits the potentiality of Madhupur National Park for natural restoration which also emphasizes the conservation needs of the natural ecosystem functioning from disturbances. The major causes of depletion of Sal forests of Madhupur National Park were due to the clearance of land for agriculture, forest fire, fuel wood 
collection, litter collection and forest land encroachment by settlement. Almost half of the total Sal forests of the country have already been depleted (Iftekhar and Hoque 2005). The surrounding people collect fuel wood for daily cooking and earning a part of their livelihood by selling the fuel

Table 2. Seedlings stock of 5 major tree species with stem per hectare showing recruitment percentage at Madhupur National Park.

\begin{tabular}{lccc}
\hline Name of species & $($ Stem/ha & Seedling density/ha & Recruitment $(\%)$ \\
\hline Shorea robusta & 1069 & 18046 & 6 \\
Terminalia bellirica & 30 & 2490 & 1 \\
Grewia nervosa & 23 & 1571 & 2 \\
Mallotus philippensis & 61 & 3084 & 2 \\
Protium serratum & 33 & 307 & 11 \\
\hline
\end{tabular}

wood in the local market. Hossain et al. (2013b) reported that 59\% of the surrounding people use $6-10 \mathrm{~kg}$ wood for their daily cooking purpose, most of which is collected from the Sal forests. The conflict of interest and land occupancy right among the local ethnic community (Garo) and forest department is another major challenge for sustainable management of the Madhupur National Park. In this circumstance, enforcement of forest laws and implementation of conservation and restoration initiative is in a great challenge. Moreover, awareness raising and consciousness among the local people regarding the importance of forestry, wildlife, environmental conservation, biodiversity and endangered ecosystems should be mandatory.

\section{Acknowledgements}

The authors are grateful to Bangladesh Forest Department for providing the financial and logistic supports, and advice for carrying out the study under the SRCWP project. They are thankful to taxonomists of BFRI and Department of Botany, University of Chittagong, for identification of the plant samples of Madhupur National Park.

\section{References}

Alam MK 1995. Diversity in the woody flora of Sal (Shorea robusta) forest of Bangladesh. Bangladesh J. Forest Sci. 24(1): 41-51.

Barnes BV, Zak DR, Denton SR and Spurr SH 1998. Forest Ecology, 4th edition, New York: John Wiley and Sons.

Begum R 2011. People's livelihoods and involvement in co-management of Madhupur National Park, Bangladesh. USAID Contract No EPP-I-00-06-00007-00. pp. 156-170

Berhane A, Totland and Moe SR 2013. Woody plant assemblage in isolated forest patches in a semi-arid agricultural matrix. Biodiversity Conserv. 22:2519-2535.

Chowdhury B, Hossain MK, Hossain MA and Khan BM 2018a. Native tree species diversity of Rampahar Natural Forest Reserve in Rangamati South Forest Division, Bangladesh. Ceylon Journal of Science 47(2): 129-136.

Dallmeier F, Kabel M and Rice R 1992. Methods for long-term biodiversity inventory plots in protected tropical forests. In: Dallmeier (ed.), Long-term monitoring of biological diversity in tropical forest areas methods for establishment and inventory of permanent plots, MAB digest II, UNESCO, Paris. pp 11-46. 
Das SC, Alam MS and Hossain MA 2018. Diversity and structural composition of species in dipterocarp forests: A study from Fasiakhali Wildlife Sanctuary, Bangladesh. Journal of Forestry Research 29(4): $1-9$.

Deb JC, Roy A and Wahedunnabi M 2015. Structure and composition of understory treelets and overstory trees in a protected area of Bangladesh. Forest Science and Technology 11(2): 76-85.

Han Y and Wang Z 2002. Spatial heterogeneity and forest regeneration. Chinese Journal of Applied Ecology 13: 615-619.

Harun-Or-Rashid S and Mia M 2001. Angiospermic flora of Madhupur National Park, Tangail, Bangladesh. Bangladesh J. Plant Taxon. 8(2): 63-82.

Hossain MA, Hossain MK and Hossain MD 2013a. Natural regeneration potential of native tree species in Dudhpukuria-Dhopachari Wildlife Sanctuary of Chittagong, Bangladesh. Bangladesh Journal of Forest Science 32(2):15-25.

Hossain MN, Rokanuzzaman M, Rahman MA, Bodiuzzaman M and Miah MA. 2013b. Causes of deforestation and conservation of Madhupur Sal forest in Tangail region. J. Environ. Sci. \& Natural Resources 6(2): 109 -114.

Hossain MK and Hossain MA 2014. Biodiversity of Chunati Wildlife Sanctuary: Flora, Arannayk Foundation and Bangladesh Forest Department, Dhaka, Bangladesh. pp. iv+176.

Hossain MK, Rahman ML, Hoque ATMR and Alam MK 2004. Comparative regeneration status in a natural forest and enrichment plantations of Chittagong (South) Forest Division, Bangladesh. Journal of Forestry Research 15(4): 255-260.

Iftekhar MS and Hoque AKF 2005. Causes of forest encroachment: An analysis of Bangladesh. Geo Journal 62(1-2): (Netherlands: Springer).

Kamruzzaman M, Hossain MA, Jannat M and Hossain MK. 2018. Regeneration status of Babu Para Village Common Forest (VCF) in Bandarban District, Bangladesh. AASCIT J. Biol. 4(1): 15-20. Available at: http://www.aascit.org/journal/biology

Malaker JC, Rahman MM, Azad-ud-Doula Prodhan AKM, Malaker SK and Awal DMA 2010. Floristic composition of Madhupursal forest in Bangladesh. J. Soil Nature 4(1): 25-33.

Misbahuzzaman K and Alam MJ 2006. Ecological restoration of rainforest through aided natural regeneration in the denuded hills of Sitakunda, Chittagong, Bangladesh. International Journal of Agriculture and Biology 8(1): 778-782.

Misra R 1968. Ecology Workbook. New Delhi, India: Oxford and IBH Publishing.

Mondol, 2013. Study on soil, plant species and encroachment status of Sal forest in Bangladesh. Dept. of Horticulture, Bangladesh Agricultural University, Mymensingh (PhD Thesis).

Motaleb MA and Hossain MK 2011. Assessment of tree species diversity of Tankawati natural forests, Chittagong (South) Forest Division, Bangladesh. Eco-Friendly Agril. J. 4(02): 542-545.

Nur A, Nandi R, Jashimuddin M and Hossain MA 2016. Tree species composition and regeneration status of Shitalpur forest beat under Chittagong north forest division, Bangladesh. Advances in Ecology pp. 1-8.

Prain D 1903. Bengal Plants. Vol. 1 \& 2. Bishen Singh Mahendra Singh Pal Singh, Dehra Dun, India (Reprinted 1981).1319 pp.

Rahman, MA, Alim MA, Hossain MK and Hossain MA. 2019. Prospect of natural regeneration of tree species in Hazarikhil Wildlife Sanctuary of Chittogram, Bangladesh. J. Biodivers. Conserv. Bioresour. Manag. 5(2): 1-12. Available at: https://doi.org/10.3329/jbcbm.v5i2.44909

Rahman MH, Khan MASA, Roy B and Fardusi MJ 2011. Assessment of natural regeneration status and diversity of tree species in the biodiversity conservation areas of northeastern Bangladesh. Journal of Forestry Research 22(4): 551-559.

Rahman MR, Hossain MK, Hossain MA and Haque MS 2017. Floristic composition of Madhupur National Park, Tangail, Bangladesh. Bangladesh Agriculture 7(1): 27-45.

Rahman MR, Rahman MM and Chowdhury MA 2019a. Assessment of natural regeneration status: The case of Durgapur hill forest, Netrokona, Bangladesh. Geology, Ecology, and Landscapes. 
Sattar AM 1977. Working plan for the Government Managed Forest of Northern Forest Division, 1975 -76 to 1984-85.

Shukla RS and Chandel PS 2000. Plant Ecology and Soil Science (9th ed.). Ramnagor: S. Chand and Company Limited, New Delhi, India, pp. 121-376.

Taketay D 1996. Seed ecology and regeneration in dry Afromontane forests of Ethiopia. Swedish University of Agricultural Sciences, Sweden. p. 174.

Wang H, Li G, Yu D and Chan Y 2008. Barrier effect of litter layer on natural regeneration of forests: A review. Chinese Journal of Ecology 27: 83-88.

Wilcox C, Cairns BJ and Possingham HP 2006. The role of habitat disturbance and recovery in meta population persistence. Ecology 87: 855-863.

(Manuscript received on 2 April, 2019; revised on 25 February, 2020) 